\title{
Effect of Ga/Cu Ratio on Polycrystalline CuGaSe 2 Thin Film Solar Cell
}

\author{
M. M. Islam, ${ }^{1,2}$ A. Yamada, ${ }^{3}$ T. Sakurai, ${ }^{1}$ S. Ishizuka, ${ }^{3}$ K. Matsubara, ${ }^{3}$ \\ S. Niki, ${ }^{3}$ and K. Akimoto ${ }^{1}$ \\ ${ }^{1}$ Institute of Applied Physics, University of Tsukuba, 1-1-1 Tennodai, Tsukuba, Ibaraki 305-8573, Japan \\ ${ }^{2}$ Research Center for Advanced Science and Technology (RCAST), The University of Tokyo, 4-6-1 Komaba, Meguro-Ku, \\ Tokyo 153-8904, Japan \\ ${ }^{3}$ Research Center for Photovoltaics, National Institute of Advanced Industrial Science and Technology (AIST), Tsukuba, \\ Ibaraki 305-8568, Japan
}

Correspondence should be addressed to M. M. Islam, monirul@mbe.rcast.u-tokyo.ac.jp

Received 30 April 2011; Accepted 1 June 2011

Academic Editor: Surya Prakash Singh

Copyright (C) 2011 M. M. Islam et al. This is an open access article distributed under the Creative Commons Attribution License, which permits unrestricted use, distribution, and reproduction in any medium, provided the original work is properly cited.

\begin{abstract}
Structural and electrical properties of polycrystalline $\mathrm{CuGaSe}_{2}$ thin films have been studied by changing the $\mathrm{Ga} / \mathrm{Cu} \mathrm{ratio}$ in the films. $\mathrm{CuGaSe}_{2}$ thin films with various $\mathrm{Ga} / \mathrm{Cu}$ ratio were grown over Mo-coated soda-lime glass substrates. With the increase of Ga content in $\mathrm{CuGaSe}_{2}$, morphology of the films was found to deteriorate which is associated with the smaller grain size and the appearance of impurity phases presumably due to the phase transition from the chalcopyrite structure to the defect-related phase on the surface of the films. Properties of the Ga poor films were affected by the $\mathrm{Cu}$ rich secondary phases. Electrical properties of the films were strongly influenced by the structural properties and degraded with increasing the $\mathrm{Ga} / \mathrm{Cu}$ ratio in the film. Device performances, fabricated with the corresponding $\mathrm{CuGaSe}_{2}$ films, were found to be correlated with the $\mathrm{Ga} / \mathrm{Cu}$ ratio in the films and consistent with the observed structural and electrical properties.
\end{abstract}

\section{Introduction}

Chalcopyrite $\mathrm{Cu}(\mathrm{In}, \mathrm{Ga}) \mathrm{Se}_{2}$, abbreviated as CIGS, is one of the most promising materials to realize high-efficiency, lowcost thin film solar cell. Efficiency of $19.9 \%$ has already been achieved for the CIGS-based solar cell [1]. As the ideal CIGS bandgap for highest conversion efficiency is speculated theoretically to be around $1.4 \mathrm{eV}$ [2], $\mathrm{CuGaSe}_{2}$ $(x=\mathrm{Ga} / \mathrm{In}+\mathrm{Ga}=1.0)$ with a bandgap of $1.68 \mathrm{eV}$ [3] can be considered as a leading material to enable the highest possible efficiency. Moreover, the large band gap makes the $\mathrm{CuGaSe}_{2}$, an ideal absorber material for the top cell in a photovoltaic tandem device together with $\mathrm{CuInSe}_{2}$ as the bottom cell absorber [4]. However, so far, $\mathrm{CuGaSe}_{2}$ solar cells with a CdS buffer have achieved efficiency of around 9.3\% for thin film [5] and $9.7 \%$ for single crystal solar cells [6]. Therefore, a better understanding of the material properties of $\mathrm{CuGaSe}_{2}$ is needed to realize efficiency beyond the current level. The electrical, optical, and microstructural properties of CIGS films are dominated by the various intrinsic defects originated from the off stoichiometry of the film composition [7-9]. Moreover, deviation from the ideal stoichiometry during growth of this material is reported to contain some secondary phases preferably segregated on the surface of the film. Particularly, formation of the $\mathrm{Cu}(\mathrm{In}, \mathrm{Ga})_{3} \mathrm{Se}_{5}, \mathrm{Cu}(\mathrm{In}, \mathrm{Ga})_{2} \mathrm{Se}_{3.5}$, and so forth phases on the surface of the slightly $\mathrm{Cu}$-poor film $(\mathrm{Ga} / \mathrm{Cu}$-rich) and $\mathrm{Cu}-\mathrm{Se}$ related secondary phase in the $\mathrm{Cu}$-rich film is a commonly observed phenomenon in CIGS material grown by various methods $[10,11]$ and reported to have significant impact on the material properties as well as fabricated device performances $[12,13]$. Therefore, to achieve the optimized material quality of $\mathrm{CuGaSe}_{2}$ material which is compatible for highest possible efficiency, an extensive study of this material with various compositions is indispensable. Although there have been various studies reported regarding the effect of composition over the properties of CIGS thin film, in case of $\mathrm{CuGaSe}_{2}$, study of the film properties as well as solar 
cell performances in connection with the above mentioned secondary phases are scarce specially due to the relatively high defect formation energy of this defect in standard grown $\mathrm{CuGaSe}_{2}$ films. In this paper, we have systematically varied the $\mathrm{Ga} / \mathrm{Cu}$ ratio in the $\mathrm{CuGaSe}_{2}$ absorber layer to study the effect of Ga content on the electrical and structural properties of the film. Also correlation between the performances of the fabricated solar cells and various $\mathrm{Ga} / \mathrm{Cu}$ ratios in the absorber layer has been investigated.

\section{Experimental}

Polycrystalline $\mathrm{CuGaSe}_{2}$ thin films with the typical thickness of $2 \mu \mathrm{m}$ were grown over Mo-coated soda-lime glass (SLG) substrates through a three-stage coevaporation process using molecular beam epitaxy system [14]. Evaporation was done at a base pressure of approximately $1 \times 10^{-6} \mathrm{~Pa}$ from three Knudsen cells (K-cells) that were the respective $\mathrm{Cu}, \mathrm{Ga}$, and Se sources. Growth temperature of the first stage was kept at $400^{\circ} \mathrm{C}$ during coevaporation of $\mathrm{Ga}$ and Se. Temperature was increased to $520^{\circ} \mathrm{C}$ at the $2 \mathrm{nd}$ and $3 \mathrm{rd}$ stage when $\mathrm{Cu}$, Se and Ga, Se coevaporation was done, respectively. To get the uniform composition of the films, substrate was kept in constant rotation of $10 \mathrm{rpm}$ during deposition. All the samples were grown at the constant flux rate of $\mathrm{Cu}, \mathrm{Ga}$, and Se. Typical deposition time for the 1st and 2nd stage was 60 minutes and 25 minutes, respectively. The duration of the 2 nd stage was determined by the target $\mathrm{Cu} / \mathrm{Ga}$ ratio of 1.3 at the end of the 2 nd stage. Finally 3 rd stage growth time determines the final $\mathrm{Cu} / \mathrm{Ga}$ ratio in the growth $\mathrm{CuGaSe}_{2}$ film. By lengthening the duration of 3rd stage, we can reduce the $\mathrm{Cu} / \mathrm{Ga}$ ratio and vice versa. Thus, several $\mathrm{CuGaSe}_{2}$ films with various $\mathrm{Gu} / \mathrm{Cu}$ ratio have been fabricated by changing the third stage growth time. After 3rd stage of the growth, during the cooling of the substrate, $\mathrm{Cu}$ and $\mathrm{Ga}$ cell shutters were closed; however Se cell remained open for 30 minutes to irradiate Se flux to avoid reevaporation of Se from the surface of the film. Thus all the films were considered to be grown in sufficient Se environment.

Device fabrication was completed by chemical bath deposition of CdS buffer layer and successive deposition of RF-sputtered highly resistive i- $\mathrm{ZnO}$, conductive $n$-type $\mathrm{Al}: \mathrm{ZnO}$ layers, and finally $\mathrm{Al}$ grids as front electrode by thermal evaporation. The film thickness of the Mo, CdS, i- $\mathrm{ZnO}$, and $\mathrm{Al}: \mathrm{ZnO}$ layers were typically $0.8 \mu \mathrm{m}, 50 \mathrm{~nm}, 70 \mathrm{~nm}$, and $400 \mathrm{~nm}$, respectively. For the electrical characterization, $\mathrm{CuGaSe}_{2}$ was grown on SLG directly.

The composition of the grown $\mathrm{CuGaSe}_{2}$ films was measured by electron probe microanalysis (EPMA) at $15 \mathrm{kV}$ of acceleration voltage. The structural properties of the films were examined by scanning electron microscopy (SEM). Electrical properties were studied by the van der Pauw Hall measurement method at room temperature. The photovoltaic properties of the fabricated solar cells were analyzed by ESS-1000 solar simulator at room temperature. Xe lamp was used as light source to illuminate AM 1.5 sun light which corresponds to the intensity of $100 \mathrm{~mW} / \mathrm{cm}^{2}$.

\section{Results and Discussions}

3.1. Structural Properties. Microstructural properties of the $\mathrm{CuGaSe}_{2}$ thin films were studied by scanning electron microscope (SEM). Sample structure for this experiment was considered as $\mathrm{CuGaSe}_{2} / \mathrm{Mo} / \mathrm{SLG}$. Figures $1(\mathrm{a})-1(\mathrm{~d})$ show the SEM images of the surface view of several $\mathrm{CuGaSe}_{2}$ thin films grown with various $\mathrm{Ga} / \mathrm{Ca}$ in the films. The amount of the $\mathrm{Ga} / \mathrm{Cu}$ ratio in the film strongly influences the morphology and structure of the film including the grain size and shape [15]. Films with near stoichiometric composition having $\mathrm{Ga} / \mathrm{Cu}=1.05$ show the best morphology with large uniform grains as seen from Figure 1(c). No void or impurity phase was seen on the surface of the film. With increasing the Ga content in the film (Figure 1(b)), no apparent reduction in grain size was observed. However, overall morphology deteriorates. Some minor phase precipitates were observed at grain boundary locations of the facet-like grains. For further increase of the $\mathrm{Ga}$ content (e.g., $\mathrm{Ga} / \mathrm{Cu}=2.03$ ), film was found to be associated with smaller grains covered with melted-like impurity phases as seen in Figure 1(a). With an increase in the bulk $\mathrm{Ga} / \mathrm{Cu}$ ratio (i.e., with a decrease of $\mathrm{Cu}$ content) in the film above the stoichiometry, structural modification occurs which starts from the surface of the film directing along the depth of the film towards the substrates [16]. Therefore, we believe impurity phases covering the surface region of the Ga-rich films might originate from the ordered defect compounds (e.g., $\mathrm{CuGa}_{3} \mathrm{Se}_{5}$ ) which is also known as defect chalcopyrite.

General tendency of the grain size in the film being smaller with increasing $\mathrm{Ga} / \mathrm{Cu}$ ratio in our study is consistent with the observation of various authors where they reported that $\mathrm{Cu}$-rich films usually are associated with larger grains than that of $\mathrm{Cu}$-poor films [17, 18]. Schlenker et al. [19] calculated the activation energy for grain boundary motion as a function of $\mathrm{Cu}$ content in the CIGS thin films. Higher $\mathrm{Cu}$ contents lead to the lower activation energies and therefore to the formation of larger grains. This calculation explains our observation of smaller grains in Ga-rich films as seen from the surface view of the films. On the contrary, relatively smaller grain in the $\mathrm{Cu}$-rich film with $\mathrm{Ga} / \mathrm{Cu}=$ 0.89 can be explained by the formation of $\mathrm{Cu}_{2-x} \mathrm{Se}$ phases between $\mathrm{CuGaSe}_{2}$ grains, that hinder the lateral growth of the $\mathrm{CuGaSe}_{2}$ grains resulting in smaller grains [20]. Void appeared in the $\mathrm{Cu}$-rich film can be attributed to the difference of the growth rate between inherent $\mathrm{CuGaSe}_{2}$ grains and converting grains during the final stage of the film growth.

To get the structural properties of the bulk of the films, we have examined SEM images of the cross-sectional view of the similar sets of the samples, as shown in Figures 2(a)2(d). Unlike the surface morphology and grain size, the cross-sectional view was not significantly influenced by the variation of $\mathrm{Ga} / \mathrm{Cu}$ ratio in the films. Ordered columnar grains, orientated with respect to Mo back contact, were observed for the near stoichiometric film with $\mathrm{Ga} / \mathrm{Cu}=$ 1.05. No significant change in grain size and orientation was observed when Ga content in the film was increased. However, some smaller grains were accumulated at the 


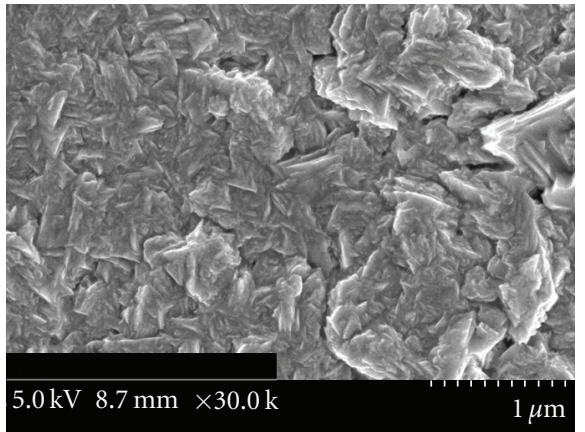

(a)

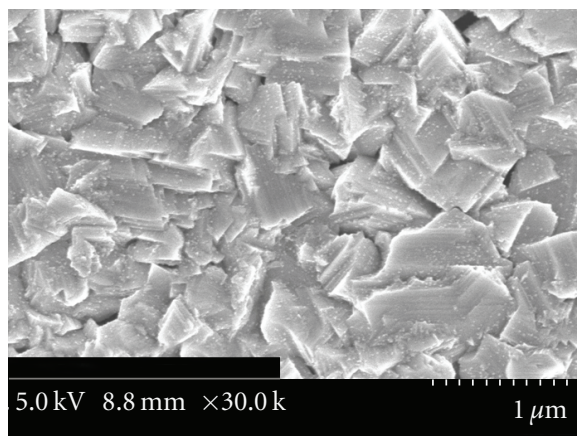

(c)

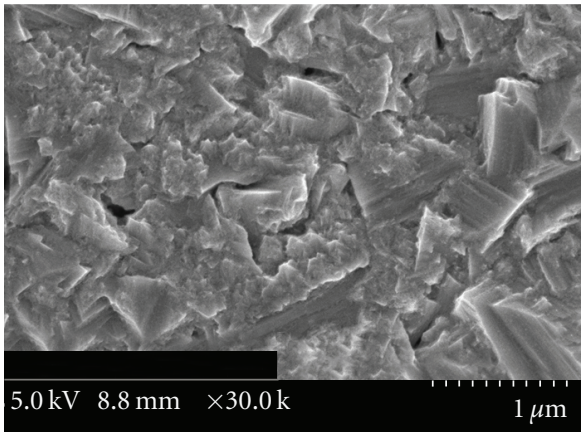

(b)

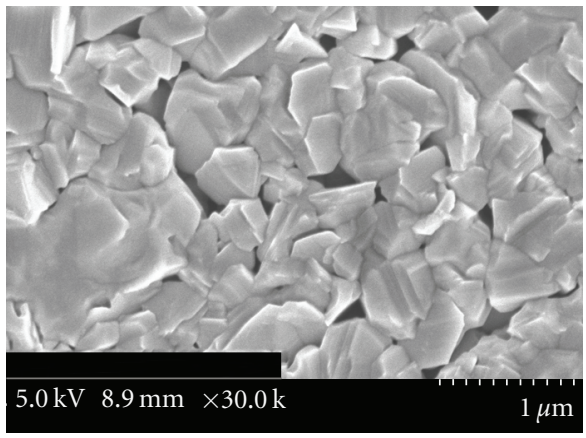

(d)

Figure 1: SEM images of the surface view of the as-grown $\mathrm{CuGaSe}_{2}$ thin films. Various $\mathrm{CuGaSe}_{2}$ layers were grown with changing $\mathrm{Ga} / \mathrm{Cu}$ ratio in the film (a) $\mathrm{Ga} / \mathrm{Cu}=2.04$, (b) $\mathrm{Ga} / \mathrm{Cu}=1.45$, (c) $\mathrm{Ga} / \mathrm{Cu}=1.05$, and (d) $\mathrm{Ga} / \mathrm{Cu}=0.89$.

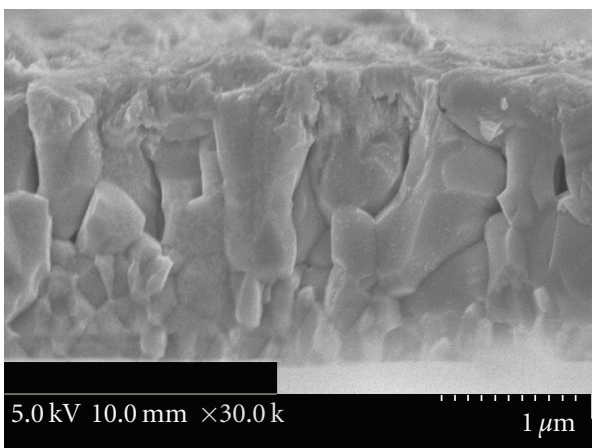

(a)

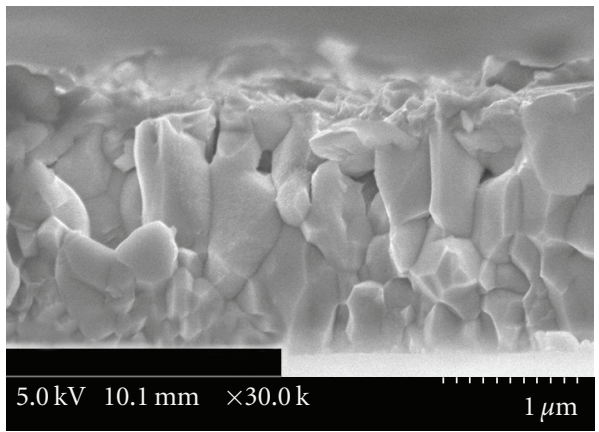

(c)

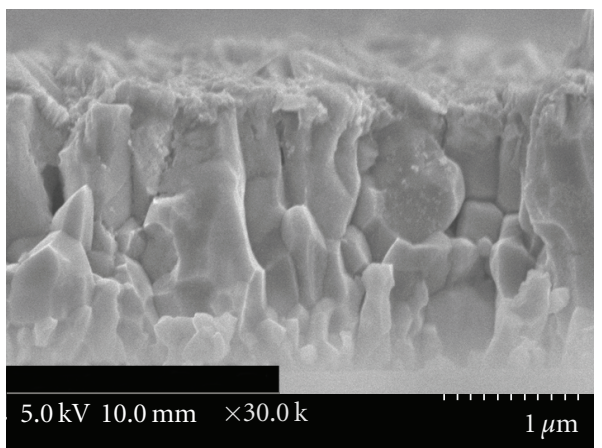

(b)

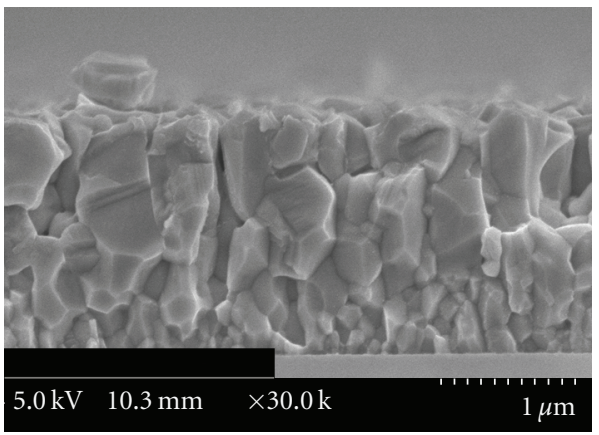

(d)

Figure 2: Cross-sectional SEM images of the as-grown $\mathrm{CuGaSe}_{2}$ thin films. Various $\mathrm{CuGaSe}_{2}$ layers were grown with changing $\mathrm{Ga} / \mathrm{Cu}$ ratio in the film (a) $\mathrm{Ga} / \mathrm{Cu}=2.04$, (b) $\mathrm{Ga} / \mathrm{Cu}=1.45$, (c) $\mathrm{Ga} / \mathrm{Cu}=1.05$, and (d) $\mathrm{Ga} / \mathrm{Cu}=0.89$. 
interface of Mo substrate and $\mathrm{CuGaSe}_{2}$ absorber. Again, highly $\mathrm{Cu}$-rich $(\mathrm{Ga} / \mathrm{Cu}=0.89)$ sample exhibits relative smaller columnar grains associated with smaller grains on the side of the Mo back contact.

We explain the above phenomenon as follows: in our three-stage growth system, $\mathrm{Cu}$ and Se material were coevaporated at the 2 nd stage of growth process. To get overall improved electrical properties with larger grain size, $\mathrm{Cu}$ flux was irradiated until $\mathrm{Cu} / \mathrm{Ga}$ in the film becomes 1.3 at the end of the 2nd stage [21]. Therefore, the columnar-grain orientation and size along the depth towards the substrate should be nominally similar up to second stage of the growth process. However, according to the phase diagram, under this $\mathrm{Cu}$-rich condition, excess $\mathrm{Cu}$ can only be in form of $\mathrm{Cu}-\mathrm{Se}$ phase in $\mathrm{Cu}-\mathrm{Ga}-\mathrm{Se}$ system [22] that preferably segregates on the surface of the film along the growth direction. According to the $\mathrm{Cu}$-Se binary phase diagram [22], $\mathrm{Cu}-\mathrm{Se}$ can exist as quasiliquid form at the growth temperature of $\sim 520^{\circ} \mathrm{C}$ at the 2nd stage. Therefore, finally, at the 3rd stage of the growth procedure, when this quasiliquid phase is exposed to the $\mathrm{Ga}$ and Se fluxes under the environment of sufficient Se vapor pressure, it contributes to form the $\mathrm{CuGaSe}_{2}$ film via several vapor-liquid-solid mechanisms $[21,23]$. The duration of the $\mathrm{Ga}$ and Se flux irradiation finally decides overall $\mathrm{Ga} / \mathrm{Cu}$ ratio in the film. For Ga-rich samples in our study, the longer duration of Ga and Se flux assists excess $\mathrm{Ga}$ and Se to incorporate into the solid system through the formation of $\mathrm{V}_{\mathrm{Cu}}$ and $\mathrm{Ga}_{\mathrm{Cu}}$ antisites defect which eventually initiate structural transition at the near surface region. This structural reformation produces defect chalcopyrite phase, for example, $\mathrm{CuGa}_{3} \mathrm{Se}_{5}$ and so forth, starting from the surface along the depth of the film. Therefore, surface of the film should exhibit primarily the characteristic change in grain size and morphology, while bulk of the film may remain nearly identical as observed from the cross-sectional view of the samples in this study. Then, relatively smaller columnar grains, observed at the film with $\mathrm{Ga} / \mathrm{Cu}=0.89$ $(\mathrm{Cu} / \mathrm{Ga} \sim 1.12)$, can be explained by the variation of growth procedure where composition at the end of the 2 nd stage may exceed the threshold value of $\mathrm{Cu} / \mathrm{Ga}=1.3$.

3.2. Electrical Properties. For the Hall effect measurement, $\mathrm{CuGaSe}_{2}$ films were grown directly over SLG and cut into $5 \times 5 \mathrm{~mm}^{2}$ of sizes. Indium was used as ohmic contact electrode. Table 1 lists the majority carrier concentration and the electrical resistivity of several $\mathrm{CuGaSe}_{2}$ films grown with various $\mathrm{Ga} / \mathrm{Cu}$ ratio in the film. The film with lower $\mathrm{Ga} / \mathrm{Cu}$ ratio $(\mathrm{Cu}$ at. $\%=26.15)$ has the resistivity of $16.1 \Omega-\mathrm{cm}$ which increased up to value of $99.4 \Omega$-cm when increasing the $\mathrm{Ga} / \mathrm{Cu}$ ratio to 2.04 (i.e., reducing the $\mathrm{Cu}$ content to 15 at. \% ). The resistivity thus depends on the $\mathrm{Ga} / \mathrm{Cu}$ ratio in the film. Similarly the hole carrier concentration generally decreases with increasing $\mathrm{Ga} / \mathrm{Cu}$ ratio in the film.

The general tendency of the increasing of resistivity and decreasing of hole carrier concentration with increasing $\mathrm{Ga} / \mathrm{Cu}$ ratio in our films can be explained by the structural
TABLE 1: Electrical properties of various $\mathrm{CuGaSe}_{2}$ thin films having different $\mathrm{Ga} / \mathrm{Cu}$ ratio in the film. Electrical properties were determined by van der Pauw Hall measurement method at room temperature. $\mathrm{CuGaSe}_{2}$ films were grown directly over SLG and cut into $5 \times 5 \mathrm{~mm}^{2}$ of sizes, for the measurement.

\begin{tabular}{lcc}
\hline $\mathrm{Ga} / \mathrm{Cu}$ & Resistivity $(\Omega-\mathrm{cm})$ & Carrier concentration $\left(\mathrm{cm}^{-3}\right)$ \\
\hline 0.89 & 88.5 & $5.8 \times 10^{15}$ \\
0.96 & 16.1 & $2.0 \times 10^{16}$ \\
1.05 & 16.3 & $1.5 \times 10^{16}$ \\
1.45 & 34.2 & $6.9 \times 10^{15}$ \\
2.04 & 99.4 & $6.0 \times 10^{15}$ \\
\hline
\end{tabular}

properties as studied by SEM images in Figures 1(a)1(d). The lowering of $\mathrm{Cu}$ content (i.e., increasing $\mathrm{Ga} / \mathrm{Cu}$ ratio) in the film resulted in smaller grain size which is responsible for increased grain boundary in the film. The carrier transport properties are greatly influenced by the increased grain boundary in polycrystalline thin films resulting in the increased resistivity and reduced free carrier concentration [24]. These inferior structural properties are primarily responsible for degraded electrical properties in the Ga-rich films. Thus, poor electrical properties in the film with smaller grain can explain the higher resistivity and reduced carrier concentration in our $\mathrm{Cu}$-rich film with $\mathrm{Ga} / \mathrm{Cu}=0.89$.

As we have mentioned earlier that decreasing of $\mathrm{Cu}$ content in the film is associated with the $\mathrm{V}_{\mathrm{Cu}}$ and $\mathrm{Ga}_{\mathrm{Cu}}$ antisites type defects which are the building block of ordered defect phase like $\mathrm{CuGa}_{3} \mathrm{Se}_{5}, \mathrm{CuGa}_{5} \mathrm{Se}_{8}$, and so forth. It is reported that polycrystalline $\mathrm{CuIn}_{3} \mathrm{Se}_{5}$ is $n$-type material and highly resistive with the resistivity of around $\sim 10^{7} \Omega-\mathrm{cm}$ and with lower carrier concentration [25]. Thus, taking into account that Ga-rich samples in this study could be bilayer structure of chalcopyrite and ordered defect phase, we can consider that this defect phase is one of the reasons for poor electrical properties of $\mathrm{CuGaSe}_{2}$ thin film when $\mathrm{Ga} / \mathrm{Cu}$ ratio was increased. Moreover, although we did not make a systematic study of the effect of $\mathrm{Na}$ in our grown $\mathrm{CuGaSe}_{2}$ films, the increased amount of the diffused $\mathrm{Na}$ in the Garich film (due to longer deposition time) may segregate on the surface of the film and drive to form Na-induced defect phase which is based on defect-chalcopyrite structure similar to that of $\mathrm{CuGa}_{3} \mathrm{Se}_{5}$ as proposed by Nadenau et al. [26] . Therefore, this defect phase may also affect the electrical properties of the Ga-rich film.

3.3. Solar Cell Performances. To understand the effect of $\mathrm{Ga} / \mathrm{Cu}$ variation in the absorber layer, over the solar cell performance, we have fabricated several $\mathrm{CuGaSe}_{2}$ based solar cell structure using the corresponding absorber layer. The device structure becomes $\mathrm{Al} / \mathrm{Al}: \mathrm{ZnO} / \mathrm{i}-\mathrm{ZnO} /$ $\mathrm{CdS} / \mathrm{CuGaSe}_{2} / \mathrm{Mo} / \mathrm{SLG}$. Any segregated $\mathrm{Cu}-\mathrm{Se}$ phase on the surface of all the $\mathrm{CuGaSe}_{2}$ films was etched off with $\mathrm{KCN}$ solution prior to the fabrication of following buffer layer; therefore, the effect of surface $\mathrm{Cu}$-rich phase can be discarded over the solar cell performances. The resulting illuminated $I$ $V$ characteristic curves of the fabricated $\mathrm{CuGaSe}_{2}$ solar cells 


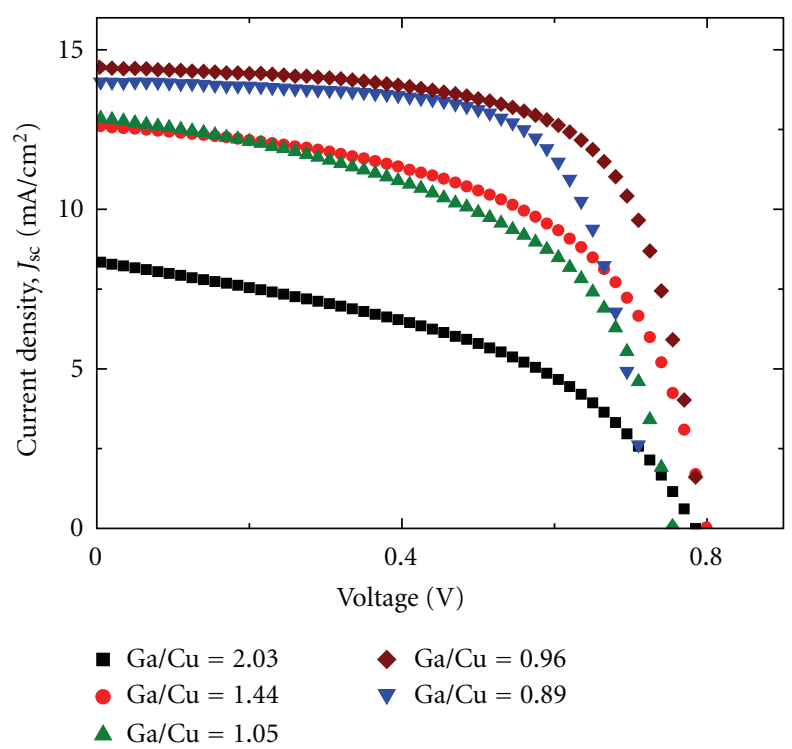

Figure 3: $I-V$ characteristics of various $\mathrm{CuGaSe}_{2}$ thin film solar cells measured by solar simulator under the illumination of AM1.5 which corresponds to the light intensity of $100 \mathrm{~mW} / \mathrm{cm}^{2}$. The active area of the cell was $0.465 \mathrm{~cm}^{2}$.

are shown in Figure 3. It is clear from the figure that all the devices suffer from the higher series resistance as evident from the slope of the higher voltage region of the curve. However, the resistivity increases with increasing $\mathrm{Ga} / \mathrm{Cu}$ ratio in the film. Also the shunt resistance is lower for the device fabricated with the $\mathrm{CuGaSe}_{2}$ absorber layer with higher $\mathrm{Ga} / \mathrm{Cu}$ ratio. The shunt resistance becomes higher with reducing $\mathrm{Ga} / \mathrm{Cu}$ ratio in the film. The higher series resistance and reduced shunt resistance in the Ga-rich $\mathrm{CuGaSe}_{2}$ based solar cell resulted in the lower fill factor in the $I-V$ curve. The poor junction properties of the Ga-rich solar cell as evident from the illuminated $I-V$ curve were also reflected in the ideality factor of the junction. An increase in the $\mathrm{Ga} / \mathrm{Cu}$ ratio in the absorber layer was found to increase the ideality factor of the solar cells as measured from the dark $I-V$ curve using a one diode model. The increased ideality factor indicates the degradation of the junction properties of the Ga-rich $\mathrm{CuGaSe}_{2}$ based solar cell associated with increased recombination centers at the absorber-buffer junction. This may arise from the formation of the junction with defect-rich phase having poor electrical properties and the buffer layer.

The performance parameters of the fabricated solar cell have been plotted in Figure 4. Open circuit voltage, $V_{\text {oc }}$, seems to be insensitive to the $\mathrm{Ga} / \mathrm{Cu}$ ratio in the film, while fill factor, FF, and short circuit current density, $J_{s c}$, were significantly influenced by the $\mathrm{Ga} / \mathrm{Cu}$ ratio. Improved $\mathrm{FF}$ and $J_{s c}$ in Cu-rich film can be explained by the improved morphology and structural properties of the absorber layer associated with improved electrical properties with increasing $\mathrm{Cu}$-content. This improved $\mathrm{FF}$ and $J_{\mathrm{sc}}$ resulted in the increase of the cell efficiency when $\mathrm{Ga} / \mathrm{Cu}$ ratio was reduced up to the near stoichiometric composition (in this study $\mathrm{Ga} / \mathrm{Cu}=0.96)$. When composition deviates from the stoichiometry to more $\mathrm{Cu}$-rich composition (more reduced

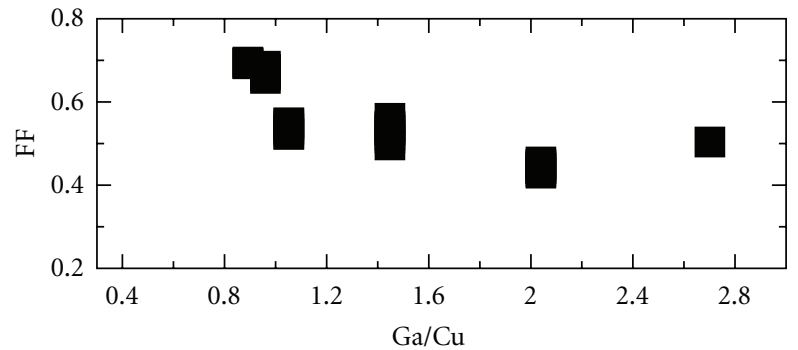

(a)

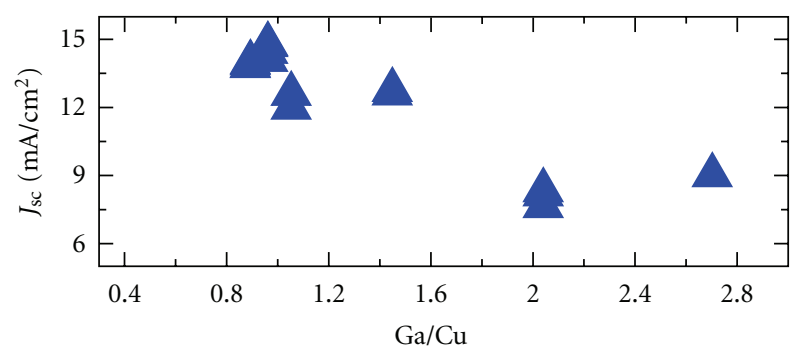

(b)

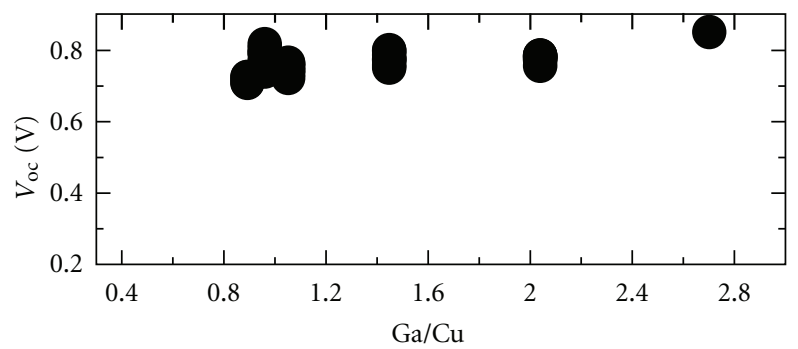

(c)

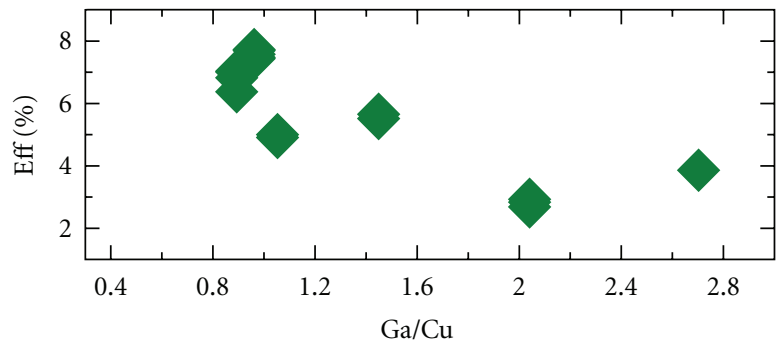

(d)

FIGURE 4: Device parameter of various $\mathrm{CuGaSe}_{2}$ thin film solar cells as a function of $\mathrm{Ga} / \mathrm{Cu}$ ratio in the $\mathrm{CuGaSe}_{2}$ absorber layer.

$\mathrm{Ga} / \mathrm{Cu}$ ratio), device performance starts to decrease mainly due to the adverse effect of $\mathrm{Cu}$-rich secondary phase in the absorber layer. Thus, $\mathrm{Ga} / \mathrm{Cu}$ ratio in $\mathrm{CuGaSe}_{2}$ film plays an important role over the performance of solar cell.

\section{Conclusion}

The effects of $\mathrm{Ga} / \mathrm{Cu}$ ratio on the properties of $\mathrm{CuGaSe}_{2}$ thin films as well as on the solar cell performance were examined. For higher $\mathrm{Ga} / \mathrm{Cu}$ ratio, over all structural properties and electrical properties of the $\mathrm{CuGaSe}_{2}$ thin films degraded which deteriorates the solar cell performance fabricated with the corresponding films. Possible origin of the degraded 
material properties of the Ga-rich films can be attributed to the formation of the $\mathrm{V}_{\mathrm{Cu}}$ and $\mathrm{Ga}_{\mathrm{Cu}}$ type defects which eventually forms $\mathrm{Cu}$-poor defect related phase of inferior material properties. On the contrary, material properties of the Gapoor (i.e., Cu-rich) samples are influenced by the formation of $\mathrm{Cu}$-Se related phase. Performance of the fabricated solar cell based on the corresponding absorber layers was found to be strongly correlated with the $\mathrm{Ga} / \mathrm{Cu}$ ratio in the films. Within the range of $\mathrm{Ga} / \mathrm{Cu}$ ratio, examined in this study, optimum $\mathrm{Ga} / \mathrm{Cu}$ ratio close to the stoichiometry was found to be preferable to get better material properties and device performance as well.

\section{References}

[1] I. Repins, M. A. Contreras, B. Egaas et al., "19.9\%-efficient $\mathrm{ZnO} / \mathrm{CdS} / \mathrm{CuInGaSe}{ }^{2}$ solar cell with $81.2 \%$ fill factor," Progress in Photovoltaics, vol. 16, no. 3, pp. 235-239, 2008.

[2] W. Shockley and H. Queisser, "Detailed balance limit of efficiency of $p$ - $n$ junction solar cells," Journal of Applied Physics, vol. 32, no. 3, pp. 510-519, 1961.

[3] S. Chichibu, T. Mizutani, K. Murakami et al., "Band gap energies of bulk, thin-film, and epitaxial layers of $\mathrm{CuInSe}_{2}$ and $\mathrm{CuGaSe}_{2}$," Journal of Applied Physics, vol. 83, no. 7, pp. 36783689, 1998.

[4] S. Nishiwaki, S. Siebentritt, P. Walk, and M. Ch. Lux-Steiner, "A stacked chalcopyrite thin-film tandem solar cell with $1.2 \mathrm{~V}$ open-circuit voltage," Progress in Photovoltaics, vol. 11, no. 4, pp. 243-248, 2003.

[5] V. Nadenau, D. Hariskos, and H. W. Schock, "CuGaSe based thin film solar cells with improved performance," in Proceedings of the 14th European Photovoltaic Solar Energy Conference, H. S. Stephens, Ed., vol. 85, pp. 1250-1253, Bedford, UK, 1997.

[6] M. Saad, H. Riazi, E. Bucher, and M. Ch. Lux-Steiner, " $\mathrm{CuGaSe}_{2}$ solar cells with 9.7\% power conversion efficiency," Applied Physics A, vol. 62, no. 2, pp. 181-185, 1996.

[7] M. M. Islam, T. Sakurai, S. Ishizuka et al., "Effect of $\mathrm{Se} /(\mathrm{Ga}+\mathrm{In})$ ratio on $\mathrm{MBE}$ grown $\mathrm{Cu}(\mathrm{In}, \mathrm{Ga}) \mathrm{Se}_{2}$ thin film solar cell," Journal of Crystal Growth, vol. 311, no. 7, pp. 2212-2214, 2009.

[8] R. Noufi, R. Axton, C. Herrington, and S. K. Deb, "Electronic properties versus composition of thin films of $\mathrm{CuInSe}_{2}$," Applied Physics Letters, vol. 45, no. 6, pp. 668-670, 1984.

[9] M. M. Islam, A. Uedono, S. Ishibashi et al., "Impact of $\mathrm{Cu} / \mathrm{III}$ ratio on the near-surface defects in polycrystalline $\mathrm{CuGaSe}_{2}$ thin films," Applied Physics Letters, vol. 98, no. 11, Article ID 112105, 2011.

[10] A. J. Nelson, A. B. Swartzlander, J. R. Tuttle, R. Noufi, R. Patel, and H. Hochst, "Photoemission investigation of the electronic structure at polycrystalline $\mathrm{CuInSe}_{2}$ thin-film interfaces," Journal of Applied Physics, vol. 74, no. 9, pp. 57575760, 1993.

[11] P. Fons, S. Niki, A. Yamada, and H. Oyanagi, "Direct observation of the $\mathrm{Cu}_{2}{ }_{x} \mathrm{Se}$ phase of Cu-rich epitaxial CuInSe ${ }_{2}$ grown on GaAs (001)," Journal of Applied Physics, vol. 84, no. 12, pp. 6926-6928, 1998.

[12] M. M. Islam, T. Sakurai, A. Yamada et al., "Determination of $\mathrm{Cu}\left(\mathrm{In}_{1-{ }_{x}} \mathrm{Ga}_{x}\right)_{3} \mathrm{Se}_{5}$ defect phase in MBE grown $\mathrm{Cu}\left(\mathrm{In}_{1-x} \mathrm{Ga}_{x}\right) \mathrm{Se}_{2}$ thin film by Rietveld analysis," Solar Energy Materials \& Solar Cells, vol. 95, no. 1, pp. 231-234, 2011.
[13] D. Schmid, M. Ruckh, F. Grunwald, and H. W. Schock, "Chalcopyrite/defect chalcopyrite heterojunctions on the basis of CuInSe ${ }_{2}$," Journal of Applied Physics, vol. 73, no. 6, pp. 29022909, 1993.

[14] K. Sakurai, R. Hunger, N. Tsuchimochi et al., "Properties of $\mathrm{CuInGaSe}_{2}$ solar cells based upon an improved three-stage process," Thin Solid Films, vol. 431-432, pp. 6-10, 2003.

[15] J. R. Tuttle, D. S. Albin, and R. Noufi, "Thoughts on the microstructure of polycrystalline thin film CuInSe $e_{2}$ and its impact on material and device performance," Solar Cells, vol. 30, no. 1-4, pp. 21-38, 1991.

[16] M. M. Islam, A. Yamada, T. Sakurai et al., "Cu-dependent phase transition in polycrystalline $\mathrm{CuGaSe}_{2}$ thin films grown by three-stage process," Journal of Applied Physics, vol. 110, Article ID 014903, 5 pages, 2011.

[17] U. Rau and H. W. Schock, "Electronic properties of $\mathrm{Cu}(\mathrm{In}, \mathrm{Ga}) \mathrm{Se}_{2}$ heterojunction solar cells-recent achievements, current understanding, and future challenges," Applied Physics A, vol. 69, no. 2, pp. 131-147, 1999.

[18] R. Klenk, T. Walter, H. W. Schock, and D. Cahen, "A model for the successful growth of polycrystalline films of $\mathrm{CuInSe}_{2}$ by multisource physical vacuum evaporation," Advanced Materials, vol. 5, no. 2, pp. 114-119, 1993.

[19] T. Schlenker, M. Luis Valero, H. W. Schock, and J. H. Werner, "Grain growth studies of thin $\mathrm{Cu}(\mathrm{In}, \mathrm{Ga}) \mathrm{Se}_{2}$ films," Journal of Crystal Growth, vol. 264, no. 1-3, pp. 178-183, 2004.

[20] R. Caballero, S. Siebentritt, K. Sakurai, C. A. Kaufmann, H. W. Schock, and M. Ch. Lux-Steiner, "Effect of Cu excess on threestage $\mathrm{CuGaSe}_{2}$ thin films using in-situ process controls," Thin Solid Films, vol. 515, no. 15, pp. 5862-5866, 2007.

[21] S. Nishiwaki, N. Kohara, T. Negami, H. Miyake, and T. Wada, "Microstructure of $\mathrm{Cu}(\mathrm{In}, \mathrm{Ga}) \mathrm{Se}_{2}$ films deposited in low Se vapor pressure," Japanese Journal of Applied Physics, vol. 38, no. 5, pp. 2888-2892, 1999.

[22] J. C. Mikkelsen Jr., "Ternary phase relations of the chalcopyrite compound $\mathrm{CuGaSe}_{2}$," Journal of Electronic Materials, vol. 10, no. 3, pp. 541-558, 1981.

[23] J. R. Tuttle, M. Contreras, M. H. Bode et al., "Structure, chemistry, and growth mechanisms of photovoltaic quality thin-film $\mathrm{Cu}(\mathrm{In}, \mathrm{Ga}) \mathrm{Se}_{2}$ grown from a mixed-phase precursor," Journal of Applied Physics, vol. 77, no. 1, pp. 153-161, 1995.

[24] M. Chen, Z. L. Pei, X. Wang et al., "Intrinsic limit of electrical properties of transparent conductive oxide films," Journal of Physics D, vol. 33, no. 20, pp. 2538-2548, 2000.

[25] T. Negami, N. Kohara, M. Nishitani, and T. Wada, "Preparation of ordered vacancy chalcopyrite-type $\mathrm{CuIn}_{3} \mathrm{Se}_{5}$ thin films," Japanese Journal of Applied Physics, vol. 33, no. 9, pp. L1251-L1253, 1994.

[26] V. Nadenau, G. Lippold, U. Rau, and H. W. Schock, "Sodium induced secondary phase segregations in $\mathrm{CuGaSe}_{2}$ thin films," Journal of Crystal Growth, vol. 233, no. 1-2, pp. 13-21, 2001. 

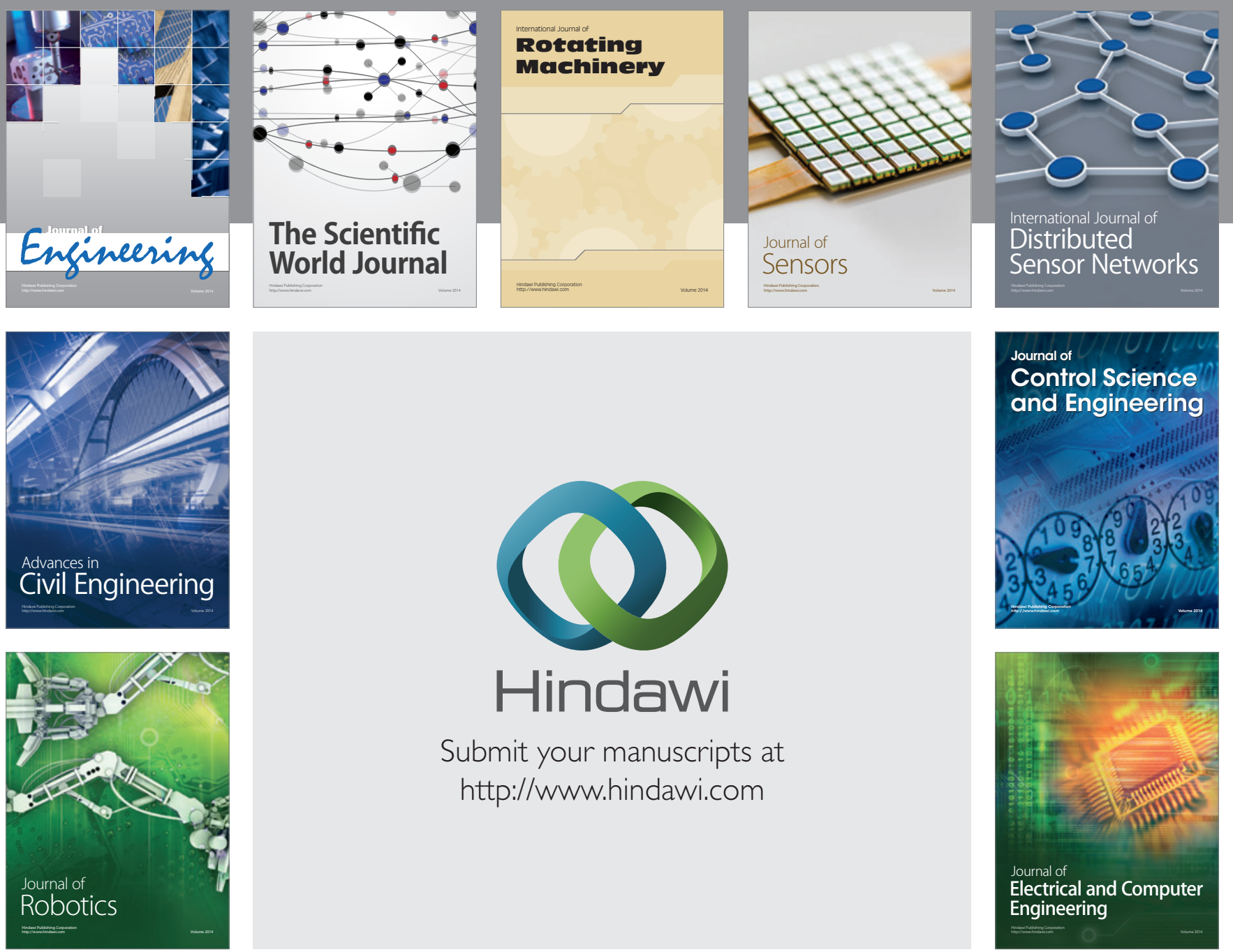

Submit your manuscripts at

http://www.hindawi.com
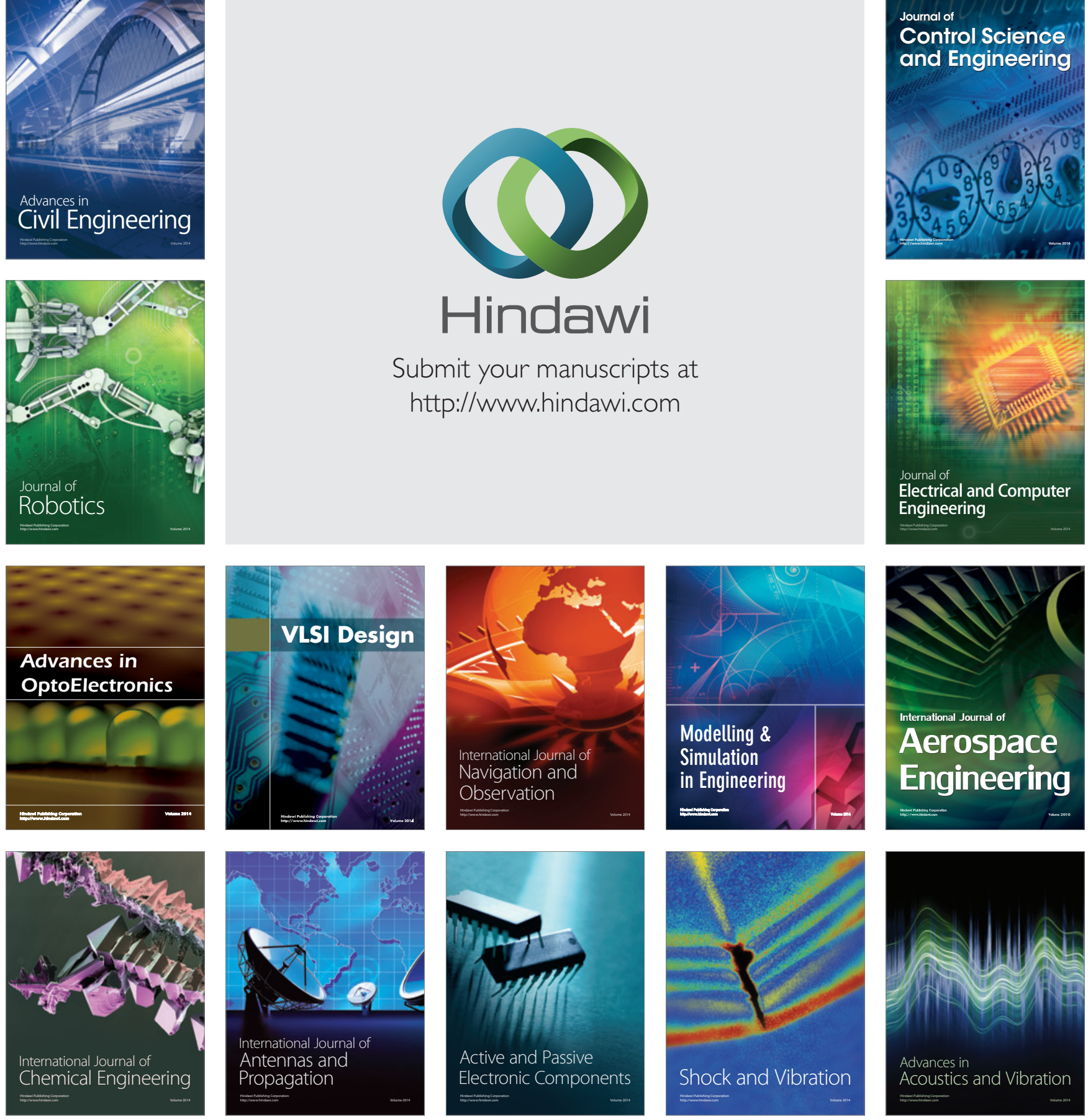